\title{
Гацаева P.C-A. \\ Многоязычие как один из путей межкультурного взаимодействия в условиях интернационализации
}

ФГБОУ ВО «Чеченский государственный университет имени А.А. Кадырова»

(Россия, Грозньй)

doi: 10.18411/trnio-01-2022-130

\section{Аннотация}

В статье рассматривается понятие межкультурной коммуникации как связи между представителями различных культур.

Ключевые слова: коммуникация, глобализация, полилингвизм, мультилингвизм, лингвокультура.

\section{Abstract}

The article examines the concept of intercultural communication as a connection between representatives of different cultures.

Keywords: communication, globalization, polylingualism, multilingualism, linguoculture.

Век, в котором мы живем, по праву можно считать веком интернационализации и глобализации. В мире развивается обширная система взаимосвязей: культурные особенности разных народов сливаются в единый поток, а электронные средства коммуникации глобализируют информацию, в результате чего формируется единое общественное сознание. В подобных условиях понятие межкультурной коммуникации как связи между представителями различных культур приобретает особую актуальность. Межкультурная коммуникация как научно-прикладная дисциплина занимается проблемами понимания и взаимопонимания: необходимо понять чужое, адекватно объяснить свое и правильно интерпретировать чужие культурные знаки. Межкультурная коммуникация имеет междисциплинарный статус. Она включает в себя знания таких наук, как культурная антропология, теория коммуникаций, этнопсихология, социология и лингвистика.

Каждая культура обладает присущим ей своеобразием, которое создается или обусловливается, по большей части, языком данной культуры. Язык необходим культурной системе для ее успешного функционирования. Изменения потребностей этой системы провоцируют изменения языковые. Многоязычием (полилингвизмом, мультилингвизмом) называют способность человека использовать несколько языков в пределах одной социальной среды. Современная наука различает два основных вида многоязычия: • социальное: наблюдается в странах с несколькими государственными языками (Канада, Швейцария) или в многонациональных государствах (Россия, страны Африки); • индивидуальное: подразумевает одинаково свободное пользование индивидом, по меньшей мере, тремя различными языками как обиходными. Термин получил широкое распространение для описания отношений между разными речевыми сообществами как в пределах отдельных государств или регионов, так и на межгосударственном уровне. Языковой барьер является наиболее очевидным препятствием на пути к межкультурному взаимопониманию. Сейчас коммуникацию между разными культурами невозможно представить без мультилингвизма. Ярчайшим примером того стала Организация Объединенных Наций, рабочими языками которой на данный момент являются английский, французский, русский, китайский, испанский и арабский. Прямая коммуникация между представителями двух различных культур требует выбора языка для их общения. С одной стороны, выбор может пасть на язык одного из коммуникантов, но в этом случае 
коммуникативный «центр тяжести» смещается в сторону носителя лингвокультуры, поскольку используемый язык является для него родным. Таким образом, знание нескольких языков может облегчить выбор языка общения, уравнивая говорящих в коммуникативном смысле. Актуальность мультилингвизма как одного из явлений социокультуры состоит в том, что владение несколькими языками - это важное условие успешной жизнедеятельности индивида и общностей в эпоху глобализации, элементом которой является взаимопроникновение материальных и духовных компонентов из разных социальных культур. Известный российский академик Владимир Иванович Вернадский не раз подчеркивал значимость изучения и владения иностранными языками. Сам ученый знал 15 иностранных языков: «Я владею (для чтения) всеми славянскими, романскими и германскими языками». Мультилингвизм - это своего рода система, которая помогает людям открыть доступ к более высокому уровню культурного развития. Обучение на любом языке предполагает изучение истории и традиций народа, являющегося носителем данного языка. Язык выступает проводником человека на пути к высокому культурному развитию, помогает индивиду самореализоваться в различных культурных областях. От качества владения языком зависит то, как быстро будут появляться возможности для использования накопленных на этом языке знаний. Многоязычие в данном контексте является ключом доступа к мировым знаниям. Оно дает возможность увеличивать межкультурные связи, знакомиться со всем тем, что создано другими народами. В эпоху глобализации успеха достигают те, кто располагает большим количеством коммуникационных ресурсов и имеет широкий спектр возможностей для распространения собственных идей. Каждая культура обладает присущим ей своеобразием, которое создается или обусловливается языком данной культуры. Поэтому полилингвизм продуктивен постольку, поскольку соблюдается принцип равенства языков и культур. В наше время выживание человечества во многом зависит от становления мировой культуры, сочетающей в себе самобытные ценности национальных культур с общечеловеческими. Основанием такого единения могут служить идеалы устойчивого развития общества, реализация которых невозможна без внимания к языковой культуре мирового сообщества, сохранения лингвистического многообразия и разумного распространения многоязычия. Полилингвизм сегодня сопряжен прежде всего с тем, что язык стал играть гораздо более важную культурную роль, чем раньше: он перестал использоваться как простое средство коммуникации, как код для передачи информации. В рамках современной цивилизации человек сам выбирает определенную комбинацию самобытных культурных черт, уходя от предопределенности. Свобода культурного самоопределения индивида, связанная с его мультилингвизмом, расширяет его умственные возможности, делает его «гражданином мира», способным верно понять те культурные факты и события, с которыми он сталкивается, но которые не принадлежат к его культуре. В полной мере этот факт отражает известная фраза «Человек столько раз человек, сколько языков он знает», авторство которой многие приписывают императору Карлу V. Язык и его система создают уникальный культурный опыт для каждого отдельного народа. Таким образом, владение несколькими языками дает возможность человеку погрузиться в совершенно новое пространство ценностей и традиций, прикоснуться к ранее далеким и неизвестным уголкам мира.

$$
* * *
$$

1. Верещагин Е.М., Костомаров В.Г. Язык и культура. - М.: Русский язык, 1990.

2. Гудков Д.Б. Теория и практика межкультурной коммуникации.- М.: Гнозис, 2003.

3. Тер-МинасоваС.Г. Язык и межкультурная коммуникация, - М.: Слово, 2008. Марков Ю.М., Амосов Е.А. 